\title{
Multiple insecticide resistance mechanisms involving metabolic changes and insensitive target sites selected in anopheline vectors of malaria in Sri Lanka
}

\author{
M Devika B Perera ${ }^{1}$, Janet Hemingway ${ }^{2}$ and SHP Parakrama Karunaratne*3
}

Address: ${ }^{1}$ Regional Office, Anti Malaria Campaign, Kurunegala, Sri Lanka, ${ }^{2}$ Vector Research Group, Liverpool School of Tropical Medicine, Pembroke Place, Liverpool, L3 5QA, UK and ${ }^{3}$ Department of Zoology, Faculty of Science, University of Peradeniya, Peradeniya, Sri Lanka

Email: M Devika B Perera - devikap10@yahoo.com; Janet Hemingway - hemingway@liv.ac.uk; SHP

Parakrama Karunaratne* - shppkaru@yahoo.com

* Corresponding author

Published: 28 August 2008

Malaria Journal 2008, 7:168

This article is available from: http://www.malariajournal.com/content/7////68

(C) 2008 Perera et al; licensee BioMed Central Ltd.

This is an Open Access article distributed under the terms of the Creative Commons Attribution License (http://creativecommons.org/licenses/by/2.0), which permits unrestricted use, distribution, and reproduction in any medium, provided the original work is properly cited.
Received: 24 November 2007

Accepted: 28 August 2008

\begin{abstract}
Background: The current status of insecticide resistance and the underlying resistance mechanisms were studied in the major vector of malaria, Anopheles culicifacies, and the secondary vector, Anopheles subpictus in five districts (Anuradhapura, Kurunegala, Moneragala, Puttalam and Trincomalee) of Sri Lanka. Eight other anophelines, Anopheles annularis, Anopheles barbirostris, Anopheles jamesii, Anopheles nigerrimus, Anopheles peditaeniatus, Anopheles tessellatus, Anopheles vagus and Anopheles varuna from Anuradhapura district were also tested.
\end{abstract}

Methods: Adult females were exposed to the WHO discriminating dosages of DDT, malathion, fenitrothion, propoxur, $\lambda$-cyhalothrin, cyfluthrin, cypermethrin, deltamethrin, permethrin and etofenprox. The presence of metabolic resistance by esterase, glutathione S-transferase (GST) and monooxygenase-based mechanisms, and the sensitivity of the acetylcholinesterase target site were assessed using synergists, and biochemical, and metabolic techniques.

Results: All the anopheline species had high DDT resistance. All An. culicifacies and An. subpictus populations were resistant to malathion, except An. culicifacies from Kurunegala, where there was no malathion carboxylesterase activity. Kurunegala and Puttalam populations of An. culicifacies were susceptible to fenitrothion. All the An. culicifacies populations were susceptible to carbamates. Both species were susceptible to the discriminating dosages of cypermethrin and cyfluthrin, but had different levels of resistance to other pyrethroids. Of the 8 other anophelines, only An. nigerrimus and An. peditaeniatus were resistant to all the insecticides tested, probably due to their high exposure to the insecticides used in agriculture. An. vagus showed some resistance to permethrin.

Esterases, GSTs and monooxygenases were elevated in both An. culicifacies and An. subpictus. AChE was most sensitive to insecticides in Kurunegala and Trincomalee An. culicifacies populations and highly insensitive in the Trincomalee An. subpictus population.

Conclusion: The complexity of the resistance segregating in these field populations underlines the need for new molecular tools to identify the genomic diversity, differential upregulation and different binding specificities of resistance conferring genes, and the presence of different subspecies with different vectorial capacities. 


\section{Background}

Malaria has been a major public health problem in Sri Lanka since ancient times. Several major malaria epidemics have occurred on the island. The most devastating of these was the epidemic in 1934/35 with more than five million cases and 80,000 deaths. Incidence of malaria declined to an extremely low level during $1958-1963$ as a result of the introduction of DDT. However, there was a resurgence of the disease in 1965 leading to a major epidemic in 1968 [1,2]. More recently, several outbreaks of malaria have occurred with varying degree of intensity. Anopheles culicifacies is the major vector of malaria, while Anopheles subpictus, under favourable ecological conditions, acts as a secondary vector $[3,4]$. Several other anophelines including Anopheles annularis, Anopheles barbirostris, Anopheles jamesii, Anopheles nigerrimus, Anopheles peditaeniatus, Anopheles tessellatus and Anopheles varuna occur on the island and several of these are potential vectors [5].

Control of malaria in Sri Lanka is primarily through the use of insecticides. Prior to 1975/77 malaria vector control programmes were based on indoor residual house spraying (IRS) of DDT. Due to development of resistance to DDT in vector mosquito populations and environmental concerns, DDT was replaced with malathion in 1975 [2]. Development of vector resistance to malathion, and increased transmission of malaria, lead to the introduction of pyrethroids for vector control programmes in Sri Lanka in 1994. At present, fenitrothion (an organophosphate) and pyrethroids such as $\lambda$-cyhalothrin, cyfluthrin, and deltamethrin or the pseudo-pyrethroid etofenprox are the major insecticides used for IRS. Rotation of chemically unrelated compounds every $3-5$ years is the strategy adopted by the Sri Lankan malaria vector control programmes to delay the development of resistance. Permethrin (a pyrethroid) is the only insecticide used for impregnation of mosquito nets. Recently, long-lasting insecticide-treated mosquito nets have been distributed in some provinces [6].

Insecticide resistance is increasingly becoming a problem for malaria vector control programmes. Widespread use of the same insecticides in the agricultural sector has made the situation worse. Resistance may develop due to changes in the mosquitoes enzyme systems, resulting in more rapid detoxification or sequestration of the insecticide, or due to mutations in the target site preventing the insecticide-target site interaction [7]. Insecticides that can be used in malaria control are increasingly becoming limited. Introduction of inappropriate insecticides without a proper understanding of the prevailing resistance mechanisms may lead to enhanced vector resistance and disease control failure. Early detection and knowledge on the resistance status and the underlying mechanisms in vector mosquitoes are essential for effective long-term control of the vector. The status of insecticide resistance and prevalence of different types of resistance mechanisms in $A n$. culicifacies and An. subpictus populations from five administrative districts of Sri Lanka is reported in this paper. Resistance in other anophelines is also discussed.

\section{Methods \\ Collection of An. culicifacies and An. subpictus mosquitoes}

Adult blood-fed female An. culicifacies and An. subpictus were collected between January 2001-December 2004 using cattle baited hut traps, from selected localities in five administrative districts of Sri Lanka; namely Paderellewa in Anuradhapura district $\left(8^{\circ} .40 \mathrm{~N}, 80.74 \mathrm{E}^{\circ}\right)$, Gadolwaka in Kurunegala district $\left(7^{\circ} .67 \mathrm{~N}, 79.94 \mathrm{E}^{\circ}\right)$, Pelwattha in Moneragala district $\left(6^{\circ} .74 \mathrm{~N}, 81.19 \mathrm{E}^{\circ}\right)$, Neelabemma in Puttalam district $\left(8^{\circ} .19 \mathrm{~N}, 80.09 \mathrm{E}^{\circ}\right)$ and Puliyankulam in Trincomalee district $\left(8^{\circ} .60 \mathrm{~N}, 81.20 \mathrm{E}^{\circ}\right)$ (Figure 1). F1 adults were obtained from field collected adults. Alternatively, larvae were collected from their natural habitats such as stream bed pools, stream margins, paddy fields

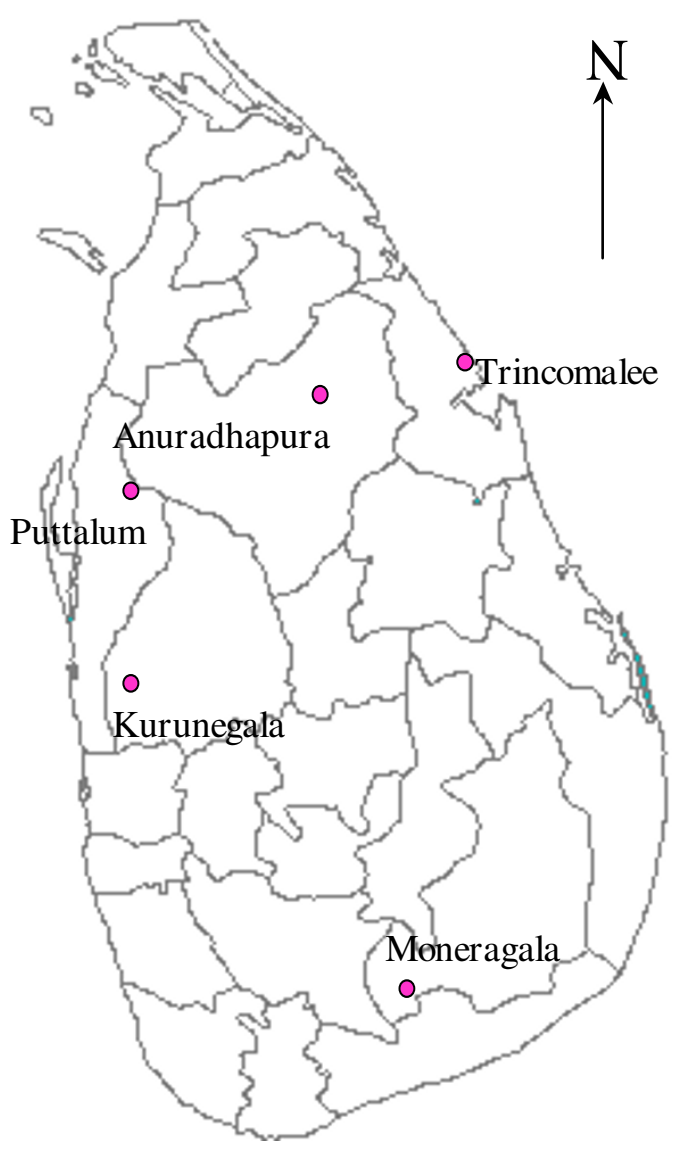

Figure I

Map of Sri Lanka showing the study sites. 
and quarry pits and reared through to adults. This procedure allowed standardizing the age and testing conditions. Two-three day old female mosquitoes were then used for all experiments.

\section{Collection of other anopheline species}

Anopheles annularis, An. barbirostris, An. jamesii, An. nigerrimus, An. peditaeniatus, An. tessellatus, An. vagus and An. varuna were collected from Paderellewa, Pennuma, Konwewa and Perimiyankulama in Anuradhapura district in 2004. Two-three day old female F1 mosquitoes were reared from collected material and used for subsequent experiments.

\section{Insecticides, chemicals and equipments}

Chemicals were purchased from Sigma chemicals U.K. unless otherwise stated. Insecticides (97-99\% pure) were from ChemService, UK. Malathion, fenitrothion, propoxur, cyfluthrin, cypermethrin, deltamethrin, etofenprox, $\lambda$-cyhalothrin and permethrin were used to prepare insecticide-impregnated papers for bioassay experiments. $\mathrm{UV}_{\max }$ kinetic plate reader and $\mathrm{KC}_{3}$ software were from Molecular Devices, Bio-Tek, U.S.A. Gel electrophoresis apparatus and protein assay kit were from BIO-RAD, U.K.

\section{Preparation of insecticide-impregnated papers and insecticide bioassays}

Insecticide-impregnated papers were prepared by the standard World Health Organization method [8]. Insecticide solutions of WHO recommended discriminating dosages were prepared by mixing the technical grade insecticide with a spreading agent. DDT (4\%), malathion (5\%), fenitrothion (1\%) and propoxur $(0.1 \%)$ solutions were prepared in olive oil. Cyfluthrin $(0.15 \%)$, cypermethrin $(0.1 \%)$, deltamethrin $(0.025 \%)$, etofenprox $(0.1 \%), \lambda$-cyhalothrin $(0.1 \%)$, and permethrin $(0.25 \%)$ solutions were made in Dow-Corning 556 silicone fluid. For permethrin, deltamethrin and $\lambda$-cyhalothrin former WHO discriminating dosages were used [9], as there is evidence to show that these are sufficient to kill $100 \%$ of all insecticide susceptible Sri Lankan vectors [10]. Rectangles of Whatman-No. 1 filter papers $(12 \mathrm{~cm} \times 15 \mathrm{~cm})$ were used for insecticide impregnation. Insecticide/oil solution $(0.7 \mathrm{ml})$ was mixed with an equal volume of acetone $(0.7$ $\mathrm{ml}$ ) and the mixture was spread uniformly on the filter paper.

Insecticide bioassays were conducted by means of tarsal contact exposure to insecticide-impregnated papers using WHO standard bioassay test kits [8]. Batches of 10-20 female mosquitoes (depending on the availability) were exposed to insecticide impregnated papers for one hour except for fenitrothion papers, for which the exposure time was two hours. Dead mosquitoes were counted after a recovery period of 24 hours. At least five replicates for each insecticide were carried out with each population. Papers impregnated with the carrier alone were used as controls. Results were used only if the mortality in the controls was $<20 \%$ and the mortalities were adjusted for using Abbott's formula [11]. WHO classification was used to interpret the results [12].

\section{Synergist studies}

Involvement of mosquito carboxylesterases and monooxygenases in insecticide resistance was further supported by carrying out synergist studies with 2-3 day old adult females from Moneragala district. Triphenyl phosphate (TPP) (10\%) was used as a carboxylesterase inhibitor and piperonyl butoxide (PB) (4\%) as a monooxygenase inhibitor. Mosquitoes were first exposed to the synergist impregnated paper for one hour and then exposed to the insecticide (malathion, fenitrothion or permethrin) impregnated paper using WHO bioassay test kits.

\section{Biochemical experiments}

Biochemical experiments were carried out by using the procedures outlined by WHO [13]. Individual mosquitoes were subjected to protein, esterase, glutathione Stransferase (GST), monooxygenase and acetylcholinesterase (AChE) assays. Adult mosquitoes $(n=200$ from each population) were individually homogenized in $150 \mu \mathrm{l}$ of ice cold distilled water. $50 \mu \mathrm{l}$ of crude mosquito homogenate was taken for the AChE assay and the remaining homogenate was centrifuged at $13,000 \mathrm{~g}$ for two minutes. To obtain specific activities of enzymes, protein concentrations of the individual homogenates were determined by Bio-Rad protein determination. In a microtitre plate well, $10 \mu \mathrm{l}$ of each homogenate was mixed with $300 \mu \mathrm{l}$ of BIO-RAD working solution (prepared according manufacturers instructions) and absorbance was read at $630 \mathrm{~nm}$ after a five minute incubation at room temperature.

\section{Esterase assay}

Ten (10) $\mu$ l of each homogenate was mixed with $200 \mu \mathrm{l}$ of $1 \mathrm{mM}$ p-nitrophenyl acetate (pNPA) working solution (100 mM pNPA in acetonitrile: $50 \mathrm{mM}$ sodium phosphate buffer pH 7.4, 1:99) in a microtitre plate well. The reaction was read immediately at $405 \mathrm{~nm}$ for two minutes as a kinetic assay at $21^{\circ} \mathrm{C}$. An extinction co-efficient of 6.53 $\mathrm{mM}^{-1}$ (corrected for a path length of $0.6 \mathrm{~cm}$ ) was used to convert the absorbance values to moles of product. Esterase specific activity per individual was reported as $\mu \mathrm{mol}$ product $\mathrm{min}^{-1} \mathrm{mg}^{-1}$ protein.

\section{Glutathione S-transferase (GST) assay}

Ten (10) $\mu$ l of each homogenate was mixed with $200 \mu \mathrm{l}$ of reduced glutathione (GSH)/1-chloro-2,4 dinitrobenzene (CDNB) working solution [95 parts of $10 \mathrm{mM}$ reduced glutathione (GSH) in $100 \mathrm{mM}$ phosphate buffer pH $6.5+$ 5 parts of $63 \mathrm{mM}$ CDNB diluted in methanol] in a micro- 
titre plate well. The reaction was read at $340 \mathrm{~nm}$ immediately as a kinetic assay for 5 minutes. An extinction coefficient of $5.76 \mathrm{mM}^{-1}$ (corrected for a path length of 0.6 $\mathrm{cm}$ ) was used to convert absorbance values to moles of product. GST specific activity was reported as CDNB conjugated $\mu \mathrm{mol}$ product $\mathrm{min}^{-1} \mathrm{mg}^{-1}$ protein.

\section{Monooxygenase estimation}

Twenty (20) $\mu$ l of homogenate was mixed with $80 \mu \mathrm{l}$ of potassium phosphate buffer pH $7.2+200 \mu$ of $6.3 \mathrm{mM}$ tetramethyl benzidine (TMBZ) working solution $[(0.01 \mathrm{~g}$ TMBZ dissolved in $5 \mathrm{ml}$ methanol and then in $15 \mathrm{ml}$ of sodium acetate buffer $\mathrm{pH} 5.0)+25 \mu \mathrm{l}$ of $3 \%(\mathrm{v} / \mathrm{v}) \mathrm{H}_{2} \mathrm{O}_{2}$ solution] in a microtitre plate well. After a two hour incubation at room temperature, the plate was read at $630 \mathrm{~nm}$ as an end-point assay. This assay does not measure the monooxygenase activity, but titrates the amount of bound haem in the mosquito homogenate. Since haem is present in the active site of monooxygenases, major changes in the amount of monooxygenases produces a measureable increase in haem. By using a standard curve of cytocrome $\mathrm{C}$ (which also contains bound haem) a crude estimate of the amount of the monooxygenases present was obtained and expressed as equivalent units of cytocrome P450.

\section{Malathion metabolism}

Batches (25) of adult mosquitoes were homogenized in $0.5 \mathrm{ml}$ of $25 \mathrm{mM}$ Tris-HCl buffer ( $\mathrm{pH} 7.5$ ) and centrifuged at $13,000 \mathrm{~g}$ for 5 minutes. Supernatant was incubated with $300 \mu \mathrm{M}$ malathion for $2 \mathrm{hrs}$ at room temperature. The samples were then extracted with two volumes of $0.5 \mathrm{ml}$ acidified chloroform and dried under an air current. The extract was re-suspended in $30 \mu \mathrm{l}$ acidified chloroform and loaded onto a silica gel thin layer chromatography (TLC) plate. The plate was eluted with a mobile phase consisting of $n$-hexane: diethyl ether (1:3). After the run the plate was sprayed with a $0.5 \%(\mathrm{w} / \mathrm{v}) 2,6$-dibromoquinone 4-chloromide in cyclohexane and left at $100^{\circ} \mathrm{C}$ for 2 hrs to visualize spots of malathion and its metabolic products. Buffer $(0.5 \mathrm{ml})$, incubated with $300 \mu \mathrm{M}$ malathion and $300 \mu \mathrm{M}$ sodium hydroxide $(\mathrm{NaOH})$ was run as a positive control. Buffer $(0.5 \mathrm{ml})$, incubated with the same concentration of malathion, was run as a negative control.

\section{Acetylcholinesterase (AChE) assay}

Two, $20 \mu$ replicates from each mosquito homogenate were placed in adjacent wells of a microtitre plate. The membrane bound AChE in the mosquito homogenate was solubilized by adding $145 \mu$ of Triton phosphate buffer $[1 \%(\mathrm{v} / \mathrm{v})$ Triton X-100 in $0.1 \mathrm{M}$ phosphate buffer $\mathrm{pH}$ 7.8] to each. To one set of homogenates, $25 \mu \mathrm{l}$ of 0.01 $\mathrm{M}$ acetylthiocholine iodide (ASChI) and $10 \mu \mathrm{l}$ of $0.1 \mathrm{M}$ propoxur solution $(2.5 \mathrm{ml} 0.1 \mathrm{M} \mathrm{ASChI}+10 \mu \mathrm{l}$ of $0.1 \mathrm{M}$ propoxur in acetone) were added. To the other replicate, $25 \mu$ l of ASChI alone was added. The kinetics of the enzyme reaction was continuously monitored at $405 \mathrm{~nm}$ for five minutes. Results were expressed as a percentage remaining activity in the inhibited fraction compared to the control (uninhibited) activity.

\section{Polyacrylamide gel electrophoresis (PAGE)}

Native PAGE was used to visualize the pattern of elevated esterase isozymes present in different populations. A mass homogenate of 25 mosquitoes from each population was made in $250 \mu \mathrm{l}$ of $50 \mathrm{mM}$ sodium phosphate buffer $(\mathrm{pH}$ 7.4). Electrophoresis of 10,000 g supernatants from crude homogenates was performed in $7.5 \%$ acrylamide gels in tris/borate buffer pH 8.0 containing $0.2 \mathrm{mM}$ EDTA. Gels were stained for esterase activity with $0.04 \%(\mathrm{w} / \mathrm{v}) \alpha$ - and $\beta$-naphthyl acetate and $0.1 \%(\mathrm{w} / \mathrm{v})$ Fast Blue B dye in 100 mM phosphate buffer ( $\mathrm{pH} 7.4$ ). Purple ( $\alpha$-naphthyl acetate preferred) and/or pink ( $\beta$-naphthyl acetate preferred) esterase bands were identified and the rate of flow $\left(R_{f}\right)$ was calculated for each band.

\section{Results}

The results of adult bioassays, conducted with discriminative dosages of selected insecticides for An. culicifacies and An. subpictus populations from different districts are presented in Table 1.

All An. culicifacies and An. subpictus populations had high levels of resistance to DDT. All An. culicifacies populations were highly susceptible to the carbamate propoxur. Mortality percentages observed in all An. subpictus populations suggested that the possibility of resistance against carbamates. All populations showed resistance to malathion except for An. culicifacies from Kurunegala which was fully susceptible. Possible resistance to fenitrothion was shown by the An. culicifacies from Anuradhapura (88\% mortality) and all other populations were resistant to fenitrothion ( $<80 \%$ mortality). Kurunegala and Puttalam $A n$. culicifacies populations were fully susceptible to fenitrothion. In An. subpictus, fenitrothion resistance ranged from $22 \%-60 \%$ (Table 1 ).

All the populations were susceptible to the WHO discriminating dosages of cypermethrin and cyfluthrin. Moneragala and Trincomalee both An. culicifacies and An. subpictus populations were susceptible to $\lambda$-cyhalothrin. All An. subpictus populations showed possible resistance to deltamethrin ( $84 \%-92 \%$ mortality). Resistance to permethrin occurred in all populations of both species. An. subpictus population from Anuradhapura and both An. culicifacies and An. subpictus populations from Trincomalee had very high levels of resistance to permethrin. Possible resistance to etofenprox was shown by all $A n$. culicifacies populations (mortality percentages varied from $81 \%-90 \%$ ) but, all An. subpictus populations were resistant to etofenprox (27\%-74\% mortality) with the excep- 
Table I: Percentage mortalities of Anopheles culicifacies and Anopheles subpictus populations to different insecticides ( $\mathrm{n}>100$ for each value)

\begin{tabular}{|c|c|c|c|c|c|c|c|c|c|c|}
\hline & \multicolumn{2}{|c|}{ Anuradhapura } & \multicolumn{2}{|c|}{ Kurunegala } & \multicolumn{2}{|c|}{ Moneragala } & \multicolumn{2}{|c|}{ Puttalam } & \multicolumn{2}{|c|}{ Trincomalee } \\
\hline & Ac & As & $A c$ & As & $A c$ & As & Ac & As & $A c$ & As \\
\hline $4 \%$ DDT & 34 & 20 & 4 & 14 & 62 & 30 & 24 & 47 & 22 & 19 \\
\hline $5 \%$ Malathion & 39 & 39 & 100 & 49 & 47 & 27 & 30 & 23 & 30 & 30 \\
\hline I\% Fenitrothion & 88 & 60 & 100 & 62 & 60 & 40 & 100 & 48 & 78 & 40 \\
\hline $0.1 \%$ Propoxur & 100 & 92 & 100 & 84 & 100 & 93 & 100 & 85 & 100 & 86 \\
\hline $0.1 \% \lambda$-cyhalothrin & 100 & 65 & 100 & 58 & 100 & 100 & 100 & 85 & 100 & 100 \\
\hline $0.25 \%$ Permethrin & 50 & 30 & 85 & 65 & 65 & 67 & 87 & 67 & 23 & 25 \\
\hline 0.025\% Deltamethrin & 100 & 88 & 100 & 86 & 7 & 84 & 100 & 92 & 97 & 88 \\
\hline $0.1 \%$ Cypermethrin & 100 & 100 & 100 & 100 & 100 & 100 & 100 & 100 & 100 & 100 \\
\hline $0.15 \%$ Cyfluthrin & 100 & 100 & 100 & 100 & 100 & 100 & 100 & 100 & 100 & 100 \\
\hline $0.1 \%$ Etofenprox & 95 & 27 & 89 & 67 & 85 & 62 & 85 & 74 & 90 & 100 \\
\hline
\end{tabular}

Ac $=$ An. culicifacies

As $=$ An. subpictus.

Mortality $98 \%-100 \%$ indicates susceptibility, $97 \%-80 \%$ suggests possibility of resistance that needs verification, $<80 \%$ indicate resistant [I I].

tion of the Trincomalee population, which was fully susceptible.

Results of synergist studies are given in Table 2. Pre-exposure to the esterase inhibitor TPP reduced the levels of organophosphate and pyrethroid resistance in both species. The monooxygenase inhibitor $\mathrm{PB}$ reduced the level of pyrethroid resistance. In contrast, inhibition of monooxygenases by $\mathrm{PB}$ prevented the thionate- to oxon - analogue conversion of organophosphates within the insect increasing the organophosphate resistance. The synergist data shows the importance of esterases and monooxygenases in organophosphate and pyrethroid resistance.

To obtain esterase, glutathione S-transferase and monooxygenase activity profiles, bar charts were constructed to obtain the percentage of the population (Y-axis) which show different activity levels (X-axis).

Activity profiles (specific activity vs percentage population) were obtained for esterases and GSTs for each population of each species (20 activity profiles) and quantity profiles for monooxygenases (equivalent units of cytocrome $\mathrm{P} 450$ vs percentage population) were also plotted for all the populations (10 quantity profiles). After a through analysis of all the profiles (figures not shown), activity peaks corresponding to homozygous susceptible, heterozygous and homozygous resistance were identified. Discriminating values were then established i.e. 0.25 $\mu \mathrm{mol} / \mathrm{mg} / \mathrm{min}$ esterase activity, $0.40 \mu \mathrm{mol} / \mathrm{mg} / \mathrm{min}$ GST activity and 0.35 equivalent units of monooxygenase amounts, and the percentages of mosquito populations which show more than these values are presented in Table 3 .
Esterase activities of An. culicifacies populations were marginally higher than An. subpictus populations. The highest esterase activities were found in Anuradhapura and Kurunegala An. culicifacies populations, while the lowest was in An. subpictus from Trincomalee. Elevation of esterases was evident from gel electrophoresis studies as well. Native PAGE resolved one elevated esterase band from $A n$. culicifacies $\left(\mathrm{R}_{\mathrm{f}}=0.66\right)$ and a different elevated esterase from $A n$. subpictus $\left(\mathrm{R}_{\mathrm{f}}=1.12\right)$ and the intensity of the bands were higher in the populations which had higher levels of esterase activities. Anopheles culicifacies from Trincomalee had the highest GST activity whereas An. subpictus from the same area had the lowest GST activity. Estimates of monooxygenase levels were very high for both $A n$. culicifacies and An. subpictus from Trincomalee (Table 3).

Malathion metabolism studies were undertaken on samples of both species from all five districts to determine

Table 2: Percentage mortalities of Anopheles culicifacies and Anopheles subpictus populations from Moneragala district to malathion, fenitrothion and permethrin after exposure to synergists.

\begin{tabular}{lcc}
\hline $\begin{array}{l}\text { Insecticide/ } \\
\text { Synergist }\end{array}$ & $\begin{array}{c}\text { An. culicifacies } \\
\% \text { mortality }\end{array}$ & $\begin{array}{c}\text { An. subpictus } \\
\% \text { mortality }\end{array}$ \\
\hline $\begin{array}{l}5 \% \text { Malathion } \\
\text { 10\% TPP + 5\% Malathion }\end{array}$ & 47 & 27 \\
$4 \%$ PB + 5\% Malathion & 70.9 & 96 \\
& 8.5 & 10 \\
I\% Fenitrothion & 60 & 40 \\
10\% TPP + I\% Fenitrothion & 80 & 68 \\
$4 \%$ PB + I\% Fenitrothion & 40 & 20 \\
\hline 0.25\% Permethrin & 65 & 67 \\
I0\% TPP + 0.25\% Permethrin & 72 & 50 \\
$4 \%$ PB 0.25\% + Permethrin & 92 & 96 \\
\hline
\end{tabular}


Table 3: Activity of esterases, glutathione S-transferases and monooxygenases in Anopheles culicifacies and Anopheles subpictus populations ( $n>200$ for each value)

\begin{tabular}{|c|c|c|c|c|c|c|c|c|c|c|}
\hline & \multicolumn{2}{|c|}{ Anuradhapura } & \multicolumn{2}{|c|}{ Kurunegala } & \multicolumn{2}{|c|}{ Moneragala } & \multicolumn{2}{|c|}{ Puttalam } & \multicolumn{2}{|c|}{ Trincomalee } \\
\hline & Ac & As & Ac & As & $A c$ & As & Ac & As & Ac & As \\
\hline Est ${ }^{1}$ & 52 & 10 & 51 & 18 & 44 & 21 & 30 & 17 & 15 & 06 \\
\hline $\mathrm{GST}^{2}$ & 28 & 19 & 13 & 26 & 10 & 43 & 36 & 45 & 60 & 09 \\
\hline $\mathrm{MO}^{3}$ & 24 & 38 & 38 & 28 & 56 & 27 & 27 & 20 & 72 & 86 \\
\hline $\mathrm{MCE}^{4}$ & + & + & - & ++ & +++ & +++ & + & + & +++ & +++ \\
\hline
\end{tabular}

Ac $=$ An. culicifacies

As $=$ An. subpictus

I. \% population having esterase specific activity above $0.25 \mu \mathrm{mol} / \mathrm{mg} / \mathrm{min}$

2. \% population having glutathione S-transferase specific activity above $0.40 \mu \mathrm{mol} / \mathrm{mg} / \mathrm{min}$

3. \% population having monooxygenase levels above 0.35 equivalent units of cytochrome $P_{450}$

4. malathion carboxylesterase activity as measured by malathion metabolism studies (see text for details)

- no activity ++ - moderate +++ - high

whether a malathion-carboxylesterase resistance mechanism was present in these populations. Malathion was metabolized into mono- and di-acid products by mosquito homogenates prepared from An. culicifacies and An. subpictus from all the districts, with the exception of $A n$. culicifacies from Kurunegala. Level of malathion carboxylesterase activity are given for each population in Table 3.

Biochemical assays were undertaken to determine whether there was any evidence for involvement of an altered AChE enzyme mechanism in the organophosphate and/or carbamate resistance observed in these populations. Standard concentrations of propoxur did not inhibit the AChE activity of most of the individuals in both species. The AChE target site of An. culicifacies from Kurunegala had a greater sensitivity than that of other $A n$. culicifacies populations (Table 4). Highest levels of insensitivity were shown by An. subpictus from Trincomalee with a $70 \%$ of homozygous insensitive population according to WHO classification [13]. In general, a higher frequency of heterozygous and homozygous insensitive individuals was found in all the An. subpictus populations.
Results of the insecticide bioassays carried out with other anopheline mosquitoes are presented in Table 5. All the species showed more than $40 \%$ resistance to DDT. Only An. nigerrimus and An. peditaeniatus were resistant to most of the insecticides tested. Thirty five percent of the An. vagus tested was resistant to permethrin. Biochemical assays revealed that monooxygenases are elevated in $A n$. nigerrimus, An. peditaeniatus and An. vagus populations (Table 6) (large standard deviations indicate high heterogeneity of populations).

\section{Discussion}

Prior to 1977, DDT was the insecticide used for malaria vector control programmes in Sri Lanka. This was gradually replaced by malathion, due to island-wide development of vector resistance to DDT and concerns for the environment. DDT resistance in An. culicifacies and An. subpictus was first detected in 1969 in Sri Lanka [2]. Vector resistance to DDT declined slowly after cessation of its usage, but increased again after 1983 due to a GST-based resistance mechanism, which was first selected by exposure to DDT and subsequently selected by exposure to organophosphates $[14,15]$. Use of malathion, for nearly three decades, has selected high levels of malathion resist-

Table 4: Presence of insensitive target site acetylcholinesterase (AChE) in Anopheles culicifacies and Anopheles subpictus populations [homozygous sensitive (SS), heterozygous (RS) and homozygous insensitive (RR) are given according to percentage remaining activity of AChE after insecticide inhibition (WHO, 1998)]

\begin{tabular}{|c|c|c|c|c|c|c|}
\hline & \multicolumn{3}{|c|}{$\begin{array}{l}\text { An. culicifacies } \\
\% \text { population }\end{array}$} & \multicolumn{3}{|c|}{$\begin{array}{l}\text { An. subpictus } \\
\% \text { population }\end{array}$} \\
\hline & $\begin{array}{c}\text { SS } \\
(<30 \%)\end{array}$ & $\begin{array}{c}\text { RS } \\
(30-70 \%)\end{array}$ & $\begin{array}{c}\mathrm{RR} \\
(>70 \%)\end{array}$ & $\begin{array}{c}\text { SS } \\
(<30 \%)\end{array}$ & $\begin{array}{c}\text { RS } \\
(30-70 \%)\end{array}$ & $\begin{array}{c}\mathrm{RR} \\
(>70 \%)\end{array}$ \\
\hline Anuradhapura & 31 & 42 & 27 & 31 & 53 & 16 \\
\hline Kurunegala & 70 & 25 & 5 & 22 & 52 & 26 \\
\hline Moneragala & 27 & 49 & 25 & 22 & 52 & 26 \\
\hline Puttalam & 54 & 17 & 29 & 40 & 32 & 28 \\
\hline Trincomalee & 60 & 13 & 27 & 17 & 13 & 70 \\
\hline
\end{tabular}


Table 5: Percentage mortalities of different anopheline species from Anuradhapura to different insecticides ( $\mathrm{n}>100$ for each value)

\begin{tabular}{|c|c|c|c|c|c|c|c|c|}
\hline & $\begin{array}{l}\text { Anopheles } \\
\text { annularis }\end{array}$ & $\begin{array}{l}\text { Anopheles } \\
\text { barbirostris }\end{array}$ & $\begin{array}{l}\text { Anopheles } \\
\text { jamesii }\end{array}$ & $\begin{array}{l}\text { Anopheles } \\
\text { nigerrimus }\end{array}$ & $\begin{array}{c}\text { Anopheles } \\
\text { peditaeniatus }\end{array}$ & $\begin{array}{l}\text { Anopheles } \\
\text { tessellatus }\end{array}$ & $\begin{array}{c}\text { Anopheles } \\
\text { vagus }\end{array}$ & $\begin{array}{c}\text { Anopheles } \\
\text { varuna }\end{array}$ \\
\hline 4\% DDT & 39 & 07 & 29 & 22 & 57 & 52 & 49 & 39 \\
\hline $5 \%$ Malathion & 100 & 100 & 100 & 87 & 88 & 100 & 100 & 100 \\
\hline I\% Fenitrothion & 100 & 100 & 100 & 60 & 57 & 100 & 100 & 100 \\
\hline $0.1 \%$ Propoxur & 100 & 100 & 100 & 42 & 64 & 100 & 100 & 100 \\
\hline $0.1 \% \lambda$-cyhalothrin & 100 & 100 & 100 & 57 & 73 & 100 & 100 & 100 \\
\hline $0.25 \%$ Permethrin & 100 & 100 & 100 & 29 & 47 & 100 & 65 & 100 \\
\hline $\begin{array}{c}0.025 \% \\
\text { Deltamethrin }\end{array}$ & 100 & 100 & 100 & 58 & 70 & 100 & 100 & 100 \\
\hline $0.1 \%$ Cypermethrin & 100 & 100 & 100 & 88 & 100 & 100 & 100 & 100 \\
\hline $0.15 \%$ Cyfluthrin & 100 & 100 & 100 & 80 & 100 & 100 & 100 & 100 \\
\hline $0.1 \%$ Etofenprox & 100 & 100 & 100 & 70 & 62 & 100 & 100 & 100 \\
\hline
\end{tabular}

ance among mosquito vector populations. When malathion was first introduced in Sri Lanka, a 20 minute exposure to $5 \%$ malathion gave $100 \%$ mortality in $A n$. culicifacies [16]. First survivors for this dosage were detected after two years of malathion spraying in 1979 . Resistance to the standard WHO discriminating dosage (5\% for one hour) was first observed in 1982. Increased malathion carboxylesterase activity was the major underlying mechanism for malathion resistance in An. culicifacies, while oxidases played the major role in An. subpictus [16]. However, continuous use of malathion later selected malathion carboxylesterases in An. subpictus as well [17]. A study carried out in late 1990s in a rural area of Matale district in Sri Lanka showed that both An. culicifacies and An. subpictus have developed high levels of resistance to organochlorines and organophosphates with multiple resistance mechanisms [10].

Present study shows that resistance to DDT is common in all anopheline species in Sri Lanka. Malathion resistance is present in all the An. culicifacies and An. subpictus populations tested, except in An. culicifacies from Kurunegala, where no malathion carboxylesterase activity was detected. Malathion carboxylesterases are mutated esterases which have high hydrolase activity against malathion, (which has bulky acid groups), but low hydrolase activity against other organophosphates $[18,19]$. In Sri Lanka, carbamates are used only in the agricultural sector. Carbamate resistance was detected only among the paddy field breeders i.e. An. subpictus, An. nigerrimus and
An. peditaeniatus, probably as a result of their high exposure to agricultural pesticides [20,21].

High levels of insensitive acetylcholinesterase (RS and RR) was found among the An. culicifacies and An. subpictus populations indicating a high prevalence of insensitive AChE mechanism in these populations. However, the absence of resistance to carbamate propoxur may suggest that the standard dosage of propoxur, which was established using other anopheline species, is not strong enough to inhibit unaltered AChEs of Sri Lankan An. culicifacies and An. subpictus populations.

With the exception of An. nigerrimus, all anopheline populations were completely susceptible to the WHO discriminating dosages of cypermethrin and cyfluthrin. Selection of a monooxygenases-based resistance mechanism, probably due to heavy exposure to a variety of insecticides used in agriculture, has contributed to insecticide resistance in An. nigerrimus and An. peditaeniatus. High level of susceptibility to tested organophosphates, carbamates and pyrethroids were observed in An. annularis, An. barbirostris, An. jamesii, An. tessellatus and An. varuna. Mosquito species other than An. culicifacies, An. subpictus, An. nigerrimus, An. peditaeniatus and An. vagus from Anuradhapura gave $100 \%$ mortality to $0.25 \%$ permethrin. High susceptibility to the discriminating dosages of other pyrethroids may account for the lack of resistance to some pyrethroids observed in all vector populations despite the

Table 6: Mean activity levels of insecticide detoxifying enzymes in Anopheles nigerrimus, Anopheles peditaeniatus and Anopheles vagus (n $=\mathbf{2 0 0}$ for each value).

\begin{tabular}{cccc}
\hline $\begin{array}{c}\text { Anopheline species } \\
\text { esterase activity } \mu \mathrm{mol} \mathrm{min}^{-1} \\
\mathrm{mg}^{-1}( \pm \mathrm{SD})\end{array}$ & $\begin{array}{c}\text { glutathione S-transferase activity } \mu \mathrm{mol} \mathrm{min} \mathrm{m}^{-1} \\
\mathrm{mg}^{-1}( \pm \mathrm{SD})\end{array}$ & $\begin{array}{c}\text { monooxygenase amount } \\
\text { (equivalent units of cytochrome P450) }( \pm \mathrm{SD})\end{array}$ \\
\hline An. nigerrimus & $0.06( \pm 0.07)$ & $0.13( \pm 0.10)$ & $0.63( \pm 0.4 \mathrm{I})$ \\
An. peditaeniatus & $0.09( \pm 0.08)$ & $0.15( \pm 0.16)$ & $0.58( \pm 0.52)$ \\
An. vagus & $0.16( \pm 0.13)$ & $0.24( \pm 0.20)$ & $0.89( \pm 0.87)$ \\
\hline
\end{tabular}


presence of at least one broad spectrum pyrethroid resistance mechanism.

Insecticide resistance can be due to selection of changes in insect enzyme systems, leading to rapid detoxification or sequestration of insecticide or due to alterations of the insecticide target site preventing the insecticide-target site interaction. Increased metabolic capacity is usually achieved by increased activity of monooxygenases, GSTs or esterases. Metabolic enzyme genes usually have greater plasticity than insecticide target site genes. Increased enzyme activity can be brought about by gene amplification, upregulation, coding sequence mutations or by a combination of these mechanisms. P450s can mediate resistance to all classes of insecticides. GSTs can mediate resistance to organophosphates, organochlorines and pyrethroids. Esterases can provide resistance to organophosphates, carbamates and pyrethroids which are rich with ester-bonds [22,23]. High genetic diversity has caused broad substrate specificity in insect metabolic enzymes. Isolation and characterization of candidate genes/gene families which are over-expressed in these vector populations will aid future vector control programmes.

Insects acquire target site insensitivity through point mutations. However, only a limited number of changes can decrease insecticide sensitivity without disrupting the normal physiological functions of the target site [7]. The classic leucine to phenylalanine mutation of voltage-gated sodium channel proteins, the target site of DDT and pyre- throids, was found in An. subpictus from Anuradhapura [24]. This $k d r$ type mutation was similar to that of African An. gambiae s.s. [25] indicating an independent origin of the same mutation in two different species which are geographically isolated. This shows the constraints of evolving different mutations without interrupting the physiological role of sodium channel. Insensitivity of the carbamate and organophosphate target site AChE, was detected in almost all the populations of An. culicifacies and An. subpictus. Mutations in target sites alter its binding affinities to different insecticides depending on the molecular structure of the insecticide [26]. Therefore, altered target sites do not mediate the same level of resistance to all the insecticides belong to a particular group.

Heterogeneity of vector resistance to insecticides may also be due to the presence of sibling species with different insecticide cross-resistance spectra. An. subpictus species 'A' is abundant predominantly in inland regions and moderately resistant to organophosphates whereas species ' $\mathrm{B}$ ' is confined to the coast and resistant to permethrin in Sri Lanka $[27,28]$. The presence of two An. culicifacies subspecies 'B' and 'E' has been reported for Sri Lanka. Identification of cross resistance spectra in different subspecies has become an important issue, as only sub-species ' $\mathrm{E}$ ' transmits disease [29].

Table 7 and Table 8 summarize the levels of insecticide resistance and the detected underlying mechanisms in $A n$. culicifacies and An. subpictus populations. Resistance spectra can be correlated with the prevalence of different resist-

Table 7: Insecticide cross-resistance spectra and prevalence of resistance mechanisms in different An. culicifacies populations.

\begin{tabular}{|c|c|c|c|c|c|c|c|c|c|c|c|c|c|c|c|}
\hline & DDT & Pro & Mal & Fen & $\lambda$-cy & Per & Del & Cyp & Cyf & Eto & $\mathrm{CE}$ & GST & Mono & aAChE & MCE \\
\hline Anuradhapura & $\mathrm{RR}$ & SS & RR & RS & SS & RS & SS & SS & SS & RS & + & ++ & + & ++ & ++ \\
\hline Kurunegala & RR & SS & SS & SS & SS & RS & SS & SS & SS & RS & + & ++ & + & + & - \\
\hline Moneragala & $\mathrm{RR}$ & SS & $\mathrm{RR}$ & RS & SS & RS & RS & SS & SS & RS & + & + & + & + & ++ \\
\hline Puttalam & RR & SS & RR & SS & SS & RS & SS & SS & SS & RS & ++ & ++ & + & ++ & ++ \\
\hline Trincomalee & $\mathrm{RR}$ & SS & $\mathrm{RR}$ & RS & SS & $\mathrm{RR}$ & RS & SS & SS & RS & + & +++ & ++ & ++ & +++ \\
\hline
\end{tabular}

SS = susceptible $(<10 \mathrm{R})$

RS = intermediate $(10-50 \% R)$

$\mathrm{RR}=$ resistant $(>.50 \% \mathrm{R})$ (According to Herath, 1997)

Pro $=$ propoxur

$\mathrm{Mal}=$ malathion

Fen $=$ fenitrothion

$\lambda$-cy $=\lambda$-cyhalothrin

$\mathrm{Del}=$ deltamethrin

Per $=$ permethrin

Cyp $=$ cypermethrin

Cyf $=$ cyfluthrin

Eto $=$ etofenprox

$\mathrm{CE}=$ carboxylesterase

GST = glutathione S-transferase

Mono = monooxygenase

MCE = malathion carboxylesterase

$\mathrm{aAChE}=$ altered acetylcholinesterase

$+=$ mechanism present at low level, $++=$ mechanism present at moderate level, $+++=$ mechanism present at high level $-=$ absence of mechanism 
Table 8: Insecticide cross resistance spectra and prevalence of resistance mechanisms in different An. subpictus populations.

\begin{tabular}{|c|c|c|c|c|c|c|c|c|c|c|c|c|c|c|c|}
\hline & DDT & Pro & Mal & Fen & $\lambda-\mathrm{cy}$ & Per & Del & Cyp & Cyf & Eto & $\mathrm{CE}$ & GST & Mono & aAChE & MCE \\
\hline Anuradhapura & $\mathrm{RR}$ & SS & $\mathrm{RR}$ & RS & RS & $\mathrm{RR}$ & RS & SS & SS & $\mathrm{RR}$ & + & + & + & + & ++ \\
\hline Kurunegala & $\mathrm{RR}$ & RS & $\mathrm{RR}$ & RS & RS & RS & RS & SS & SS & RS & + & + & + & ++ & +++ \\
\hline Moneragala & RR & SS & $\mathrm{RR}$ & $\mathrm{RR}$ & SS & RS & RS & SS & SS & RS & + & ++ & + & ++ & +++ \\
\hline Puttalam & $\mathrm{RR}$ & $\mathrm{RS}$ & $\mathrm{RR}$ & $\mathrm{RR}$ & RS & $\mathrm{RS}$ & SS & SS & SS & $\mathrm{RS}$ & + & ++ & + & ++ & +++ \\
\hline Trincomalee & RR & RS & RR & $\mathrm{RR}$ & SS & $\mathrm{RR}$ & RS & SS & SS & SS & + & ++ & ++ & +++ & +++ \\
\hline
\end{tabular}

SS $=$ susceptible $(<10 R)$

RS = intermediate $(10-50 \% R)$

$R R=$ resistant $(>.50 \% R)$ (According to Herath, 1997)

Pro $=$ propoxur

$\mathrm{Mal}=$ malathion

Fen $=$ fenitrothion

$\lambda$-cy $=\lambda$-cyhalothrin

Del $=$ deltamethrin

Per $=$ permethrin

Cyp = cypermethrin

Cyf $=$ cyfluthrin

Eto $=$ etofenprox

$\mathrm{CE}=$ carboxylesterase

GST = glutathione S-transferase

Mono $=$ monooxygenase

$\mathrm{MCE}=$ malathion carboxylesterase

$\mathrm{aAChE}=$ altered acetylcholinesterase

$+=$ mechanism present at low level, $++=$ mechanism present at moderate level, $+++=$ mechanism present at high level $-=$ absence of mechanism

ance mechanisms in all the populations. High resistance levels of DDT in all populations probably are due to increased levels of GST enzymes. Resistance to malathion in Anuradhapura, Moneragala, Puttalam and Trincomalee populations is probably due to qualitative and quantitative changes of carboxylesterases. Insensitive target-site AChE has also contributed to organophosphate resistance in these populations. Absence of both qualitatively changed carboxylesterase enzymes and altered AChE mechanism must have resulted high susceptibility in Kurunegala An. culicifacies population to malathion and fenitrothion. Levels of resistance to pyrethroids shown by the populations are correlated with their high monooxygenase activity levels [30].

Genomic diversity, differential upregulation and different binding specificities of resistance conforming genes and the presence of different subspecies with varying vectorial capacities have imposed severe threats to malaria vector control programmes today. The current situation unquestionably demands rapid development of simple molecular tools which are capable of resolving, in the field, the complexity which occurs at taxonomic and phenotypic levels.

\section{Conclusion}

Genomic diversity, differential upregulation and different binding specificities of resistance conforming genes and the presence of different subspecies with varying vectorial capacities have imposed severe threats to malaria vector control programmes today. The current situation unques- tionably demands rapid development of simple molecular tools which are capable of resolving, in the field, the complexity which occurs at taxonomic and phenotypic levels.

\section{Competing interests}

The authors declare that they have no competing interests.

\section{Authors' contributions}

SHPPK and JH conceived and designed the study. MDBP conducted all the experiments. All the authors analysed the data and drafted the manuscript. All authors read and approved the final manuscript.

\section{Acknowledgements}

This work was supported by National Science Foundation, Sri Lanka.

\section{References}

I. Wickramasinghe MB: Malaria and its control in Sri Lanka. Ceylon Med J 198I, 26(3): I07-II5.

2. Konradsen F, Amerasinghe FP, Hoek W Van der, Amerasinghe PH: Malaria in Sri Lanka; current knowledge on transmission and control International Water management Institute, Colombo, Sri Lanka; 2000.

3. Carter CF, Jacocks WP: Observations on the transmission of malaria by Anopheline mosquitoes in Ceylon. Ceylon Journal of Science 1929, 2:67-86.

4. Amerasinghe PH, Amerasinghe FP, Wirtz RA, Indrajith NG, Somapala W, Perera LR, Rathnayake AMS: Malaria transmission by Anopheles subpictus (Diptera: Culicidae) in a new irrigation project in Sri Lanka. J Med Entomol 1992, 29:577-58I.

5. Amerasinghe PH, Amerasinghe FP, Konradsen F, Fonseka KT, Wirtz RA: Malaria vectors in a traditional dry zone village in Sri Lanka. Am J Trop Med Hyg 1999, 60:421-429.

6. Anti-Malaria Campaign: Malaria control programme of Sri Lanka: Five Year strategic plan 2005-2009. Colombo 2005. 
7. Hemingway J, Hawkes NJ, McCarroll L, Ranson H: The molecular basis of insecticide resistance in mosquitoes. Insect Biochem Mol Biol 2004, 34:653-665.

8. World Health Organization: Insecticide resistance and vector control. Technical Report Series, Geneva 1963, 265:41-47.

9. World Health Organization: Instructions for determining the susceptibility or resistance of adult mosquitoes to organochlorine, organophosphate and carbamate insecticides-diagnostic test. WHO/VBC.8I.806.

10. Karunaratne SHPP: Insecticide resistance spectra and underlying resistance mechanisms of Sri Lankan Anopheline vectors of malaria. Southeast Asian J Trop Med Public Health 1999, 30:460-469.

II. Matsumara F: Toxicology of insecticides. Plenum Press, New York:598.

12. World Health Organization: Test procedures for insecticide resistance monitoring in malaria vectors, bio-efficacy and persistence of insecticides on treated surfaces WHO; 1998. WHO/CDS/CPC/MAL/98.12

13. World Health Organization: Techniques to detect insecticide resistance mechanisms (field and laboratory manual). Geneva 1998.

14. Hemingway J, Miyamoto J, Herath PRJ: A possible novel link between organophosphorus and DDT insecticide resistance gene in anopheles supporting evidence from fenitrothion metabolism studies. Pesticide Biochemistry and Physiology I991, 39:49-56.

15. Herath PRJ, Jayawardena KGJ: DDT resistance in Anopheles culicifacies Giles and $A$. subpictus grassi (Diptera: Culicidae) from Sri Lanka: a field study on the mechanisms and changes in gene frequency after on the mechanisms and changes in gene frequency after cessation of DDT spraying. Bull Entomol Res 1988, 78:717-723.

16. Herath PRJ, Hemingway J, Weerasinghe IS, Jayawardena KGI: The detection and characterization of malathion resistance in field populations of Anopheles culicifacies B in Sri Lanka. Pesticide Biochemistry and Physiology 1987, 29:157-162.

17. Karunaratne SHPP, Hemingway J: Malathion resistance and prevalence of the malathion carboxylesterase mechanism in populations of Sri Lankan mosquito vectors of disease. Bull World Health Organ 200I, 79:1060-1064.

18. Campbell PM, Newcomb RD, Russel RJ, Oakeshott JG: Two different amino acid substitutions in the ali-esterase, E3, confer alternative types of organophosphorus insecticide resistance in the sheep blowfly, Lucilia cuprina. Insect Biochem Mol Biol 1998 28: $139-50$.

19. Heidari R, Devonshire AL, Campbell BE, Bell KL, Dorrian SJ, Oakeshott JG, Russell RJ: Hydrolysis of organophosphorus insecticides by in vitro modified carboxylesterase E3 from Lucilia cuprina. Insect Biochem Mol Biol 2004, 34:353-363.

20. Herath PRJ, Joshi GP: Pesticide selection pressure on Anopheles subpictus in Sri Lanka: Comparison with two other Sri Lankan anophelines. Trans R Soc Trop Med Hyg 1989, 83:565-567.

21. Amerasinghe FP, Konradsen F, Fonseka KT, Amerasinghe PH: Anopheline (Diptera: Culicidae) breeding in a traditional tank-based village ecosystem in North Central Sri Lanka. Med Entomol 1997, 34(3):290-297.

22. Feyereisen R: Insect cytochrome P450. In Comprehensive Molecular Insect Science Volume 4. Edited by: Gilbert LI, Latrou K, Gill SS. Oxford, UK: Elsevier; 2005: I-77.

23. Li $X$, Schuler MA, Berenbaum MR: Molecular mechanisms of metabolic resistance to synthetic and natural xenobiotics. Annu Rev Entomol 2007, 52:23I-253.

24. Karunaratne SHPP, Hawkes NJ, Perera MDB, Ranson H, Hemingway $\mathrm{J}$ : Mutated sodium channel genes and elevated monooxygenases are found in pyrethroid resistant populations of Sri Lankan malaria vectors. Pesticide Biochemistry and Physiology 2007, 99:108-113.

25. Martinez-Torres D, Chandre F, Williamson MS, Darriet F, Berge JB, Devonshire AL, Guillet P, Pasteur N, Pauron D: Molecular characterization of pyrethroid knockdown resistance $(k d r)$ in the major malaria vector Anopheles gambiae. s.s. Insect Mol Biol 1988, 7(2): I79-184.

26. O'Reilly AO, Khambay BPS, Williamson MS, Field LM, Wallace BA, Davies TGE: Modelling insecticide binding sites in the voltagegated sodium channel. Biochem J 2006, 396:255-263.

27. Abhayawardana TA, Wijesuriya SR, Dilrukshi RK: Anopheles subpictus complex: distribution of sibling species in Sri Lanka. Indian J Malariol 1996, 33:53-60.
28. Kelly-Hope LA, Yapabandara AMGM, Wickramasinghe MB, Perera MDB, Karunaratne SHPP, Fernando WP, Abeysinghe RR, Siyambalagoda RRMLR, Herath PJR, galappaththy GNL, Hemingway J: Spatiotemporal distribution of insecticide resistance in Anopheles culicifacies and Anopheles subpictus in Sri Lanka. Trans $R$ Soc Trop Med Hyg 2005, 99:75I-76I.

29. Surendran SN, Ramasamy MS, De Silva BGDNK, Ramasamy R: Anopheles culicifacies sibling species B and E in Sri Lanka differ in longevity and in their susceptibility to malaria parasite infection and common insecticides. Med Vet Entomol 2006, 20:153-156.

30. Herath PRJ: Insecticide resistance status in disease vectors and its practical implications. International Workshop on Insecticide Resistance of Mosquito Vectors, Salatiga, Indonesia 1997.

Publish with Bio Med Central and every scientist can read your work free of charge

"BioMed Central will be the most significant development for disseminating the results of biomedical research in our lifetime. "

Sir Paul Nurse, Cancer Research UK

Your research papers will be:

- available free of charge to the entire biomedical community

- peer reviewed and published immediately upon acceptance

- cited in PubMed and archived on PubMed Central

- yours - you keep the copyright
BiolMedcentral 